\title{
Analisis Dampak Work From Home pada Anak Usia Dini di Masa Pandemi Covid-19
}

\author{
Ririn Dwi Wiresti $\bowtie$ \\ Pendidikan Islam Anak Usia Dini, Universitas Islam Negeri Sunan Kalijaga Yogyakarta \\ DOI: $\underline{10.31004 / \text { obsesi.v5i1.563 }}$
}

\begin{abstract}
Abstrak
Penelitian ini bertujuan untuk menganalisis dan mengupas secara mendalam terkait dampak wabah pandemi covid-19 pada anak usia dini menggunakan penelitian library research melalui 6 langkah yaitu penentuan topik penelitian, tinjauan literatur terkini, reduksi literatur, pengorganisasian literatur, review literatur, dan pengambilan kesimpulan. Peneliti menggunakan teknik analisis data kualitatif deskriptif. Literatur terkini merupakan sumber data yang dipakai peneliti terbagi atas dua sumber data yaitu sumber data primer antara lain ebook dan jurnal dari unicef, jurnal ilmiah internasional, dan artikel yang berkaitan dengan anak usia dini dan covid-19. Sumber data sekunder dalam penelitian ini adalah berbagai berita ter-update terkait covid-19 dan anak usia dini. Hasil dari penelitian ini menunjukkan bahwa dampak kebijakan pemerintah untuk work from home mempengaruhi ketahanan ekonomi keluarga. Dari menurunnya ekonomi keluarga tersebut muncul berbagai dampak bagi anak usia dini antara lain emosi anak tidak stabil, krisis gizi dan kesehatan anak, terjadinya gap pembelajaran, krisis keamanan dan kenyamanan, dan krisis pengasuhan anak.

Kata Kunci: covid-19; anak usia dini; bekerja dari rumah.
\end{abstract}

\begin{abstract}
This study aims to analyze and explore in depth related to the impact of the COVID-19 pandemic outbreak in early childhood using library research through 6 steps: determining the topic of research, reviewing the latest literature, selecting appropriate literature, organizing literature, reviewing literature, and drawing conclusions. Researchers used descriptive qualitative data analysis techniques. The latest literature is a source of data used by researchers divided into two data sources, namely primary data sources including ebooks and journals from UNICEF, international scientific journals, and articles relating to early childhood and COVID-19. Secondary data sources in this study are various updated news related to COVID-19 and early childhood. The results of this study indicate that the impact of government policies for work from home affects family economic resilience. From the downturn in the family economy, various impacts on early childhood emerged, including unstable children's emotions, nutritional and children's health crises, learning gaps, safety and comfort crises, and childcare crises.
\end{abstract}

Keywords: covid-19; early childhood; work from home.

Copyright (c) 2020 Ririn Dwi Wiresti

$\triangle$ Corresponding author:

Email Address : ririnwiresti@gmail.com (Yogyakarta, Indonesia)

Received 28 May 2020, Accepted 17 July 2020, Published 8 August 2020 


\section{PENDAHULUAN}

Pada akhir tahun 2019 dunia dikejutkan dengan kemunculan virus corona (Covid19), lebih dari 114 negara telah terjangkit virus ini. Delapan negara diantaranya telah mengkonfirmasi lebih dari 1000 orang tertular virus corona untuk itu WHO menyatakan virus corona sebagai PHEIC (public health emergencies international concern) yaitu kejadian luar biasa yang beresiko terhadap penularan kesehatan masyarakat antar negara dan membutuhkan respons internasional (Sebayang, 2020) . Covid-19 merupakan penyakit yang disebabkan oleh corona virus jenis baru "CO" adalah singkatan dari corona dan 'VI' untuk virus, dan ' $\mathrm{D}$ ' untuk penyakitnya. Pada zaman dahulu penyakit ini dinamakan penyakit '2019 novel coronavirus' atau lebih dikenal dengan '2019-nCov'. Virus Covid-19 ini muncul kembali dengan jenis baru yang berhubungan dan satu keluarga dengan SARS (Severe Acute Respiratory Syndrome) dan beberapa jenis flu lainnya (Bender, 2020: 2). Meskipun terdapat kesamaan karena berasal dari hewan, akan tetapi ketiga penyakit ini memiliki masa inkubasi yang berbeda. Masa inkubasi penyakit SARS sekitar 2 - 14 hari, penyakit MERS sekitar 1 - 14 hari, dan Covid-19 sekitar 1 - 14 hari sebagian muncul pada hari ke-5 (Hananti, 2020). Gejala umum yang timbul pada seseorang terjangkit covid-19 antara lain ia akan merasakan denam tinggi, batuk, dan pilek. Gelaja ini mirip dengan flu biasa, akan tetapi jika seseorang itu tidak menghiraukan dan membiarkanya maka akan masuk ke gejala yang lebih tinggi lagi yaitu ketika virus tersebut sudah menyebar di paru-paru ia akan merasakan sesak nafas sehingga kesulitan untuk bernafas. Inilah mengapa diperlukan rapid tes untuk menguji apakah positif atau negatif covid-19 sejak gejala awal. Virus corona dapat menular melalui kontak langsung dengan tetesan nafas dari seseorang yang terinfeksi, selain itu dari batuk, bersin dan bersentuhan benda atau permukaan yang terkontaminasi virus kemudian memegang wajah ( mata, hidung, dan mulut) virus ini dapat hidup di permukaan dengan batas waktu akan tetapi dapat mati jika terkena disinfektan.

Pada tanggal 2 maret 2020 kasus pertama covid-19 ditemukan di Indonesia, tercatat per tanggal 8 mei 2020 setidaknya terdapat 12.776 kasus dengan kematian sebesar 930 hal ini membuat negara indonesia terus melakukan pencegahan dan mengedukasi masyarakat untuk tetap berhati-hati dan selalu menjaga diri dari ancaman virus corona (Asia, 2020). Hingga saat ini di beberapa negara sedang berlomba-lomba untuk menemukan vaksinnya. Belum ditemukannya vaksin ini membuat negara Indonesia dan banyak negara lainnya di seluruh dunia harus belajar hidup berdampingan dengan virus corona. Mencuci tangan, memakai masker, membawa hand sanitizer ketika keluar rumah merupakan cara hidup berdampingan sesuai dengan protokol WHO. Pemerintah juga menghimbau kepada kantor layanan publik agar melaksanakan protokol covid-19 sesuai anjuran WHO antara lain menyediakan tempat cuci tangan, menyediakan hand sanitizer, mengecek suhu tubuh sebelum memasuki ruangan, menerapkan physical distancing. Segala hal dan upaya dilakukan untuk menghentikan dan memperlambat laju perkembangan virus corona. Di Indonesia pemerintah sudah mengupayakan dengan berbagai cara antara lain : (1) Isolasi diri bagi warganya yang diduga terjangkit covid-19, (2) Physical distancing yang artinya menjaga jarak antar seseorang, (3) Membatasi perjalanan nasional atau internasional, (4) Larangan untuk berkumpul atau berkerumun, (5) Penutupan toko - toko, restoran, ruang publik, hingga sekolah (C.-A. Indonesia \& Indonesia, 2020) sehingga semua aktivitas dilakukan di rumah mulai dari belajar, bekerja, dan beribadah sesuai dengan himbauan bapak Presiden Joko Widodo pada 15 maret 2020 (Dewayani, 2020). Hasil penelitian di china bahwa work from home dapat meningkatkan kinerja karyawan sebesar 13\% (Liang et al., 2015: 165).

Berbagai upaya yang telah dilakukan tersebut tentu memberikan dampak untuk berbagai pihak. Merasa tidak berguna, merasa menjadi sumber penyakit, dikucilkan di tempat tinggal sekitar, itulah dampak dari seseorang yang telah di isolasi. Dari dampak tersebut maka tidak sedikit orang melarikan diri di tengah proses isolasi selama 2 minggu. Hal ini dapat diminimalisir dengan mengedukasi masyarakat sekitar untuk mendukung satu 
dengan yang lainnya. Dampak dari upaya larangan berkumpul dan berkerumun antara lain meniadakan semua kegiatan termasuk tak'jilan, pesta pernikahan, sholat jama'ah di masjid, pengajian, dan lain sebagainya. Hal ini akan berdampak pada ekonomi masyarakat sekitar, dimana permintaan menurun dan suplay tetap. Ketidakseimbangan ini membuat harga menjadi turun drastis. Dampak dari upaya yang paling besar adalah work from home, dalam work from home ini banyak perusahaan "merumahkan" karyawannya hasil pengamatan CORE (Center Of Reform on Economics) 9,35 juta karyawan yang dirumahkan, hal ini menjadi beban berat untuk membangun ekonomi setelah pandemi (Makki, 2020). Jika pekerja yang "dirumahkan" tersebut memiliki anak usia dini tentu hal itu akan berimbas terhadap anaknya. Dalam kajian quantum learning semua anak harus hidup dengan bahagia maka pembelajaran harus menyenangkan (Porter \& Hernacki, 1999: 4 - 8). Jika anak bahagia maka otak limbiknya akan terbuka dan informasi dapat masuk dengan optimal namun sebaliknya jika anak tidak bahagia maka otak limbiknya akan sulit untuk menerima informasi (Prima, 2018: 44 - 45). Pekerja yang dirumahkan pada masa pandemi ini pastilah hatinya merasa sedih, emosinya tidak stabil, dan ekonominya juga menurun apalagi jika ayah menjadi sumber utama penghasil untuk keluarga. Hal ini akan mempengaruhi interaksi orangtua tersebut dengan anaknya, sehingga anak tidak dapat belajar dengan serius dirumah.

Orangtua sebagai 'coach' dirumah yang membantu dan memfasilitasi proses pembelajaran anak, tidak selalu berjalan dengan baik sesuai dengan harapan (Yuliawan, 2016: 47). Hal ini disebabkan karena anak tidak mau menyelesaikan tugas yang diberikan bunda guru dalam satu waktu padahal bunda guru sudah menentukan tanggal pengumpulannya, maka dari itu tidak sedikit tugas anak yang dibantu orangtua. Ketika anak belajar dirumah dengan orangtua, belum tentu semua orangtua faham tentang psikologi anak, cara mengatasi situasi hati anak yang tidak menentu, cara menstimulus anak, cara memberikan reward and punishment dengan baik dan paling utama adalah cara mengajar anak dengan baik sesuai dengan konsep psikologi anak begitu penting peran orangtua dirumah (Ulfah \& Na'imah, 2020: 20-28). Inilah sebab mengapa orangtua harus harus bersinergi dengan bunda guru untuk mengembangkan perkembangan anak dengan stimulasi yang baik dan benar sesuai dengan konsep psikologi anak. Jika hal ini tidak dilakukan maka akan terjadi perbedaan cara mengajar antara bunda guru dan ibu dirumah, hal ini akan membuat anak bingung sehingga bad mood untuk melanjutkan belajar padahal tugas dari bunda guru harus diselesaikan dan dikumpul via online pada hari tertentu. Badmood nya anak ini membuat ibu dirumah terus memotivasi dengan cara yang berkesan 'memaksa' yang menjadikan anak tambah tidak nyaman dan tidak mau mengerjakan tugas, paksaan ini terus dilakukan sampai anak mau mengerjakan tugas. Tak jarang paksaan ini dilakukan dengan berteriak atau membentak, ini sangat dilarang dalam kajian anak usia dini karena akan menimbulkan dampak negatif untuk perkembangan anak. Jika hal tersebut terjadi hingga berulang kali tentu saja akan berdampak pada perkembangan anak. Diharapkan bagi orangtua dan guru mengetahui dampak pandemi covid-19 terhadap anak usia dini. Sebab dengan mengetahui dampaknya maka orangtua dan guru dapat ikut berkontribusi untuk meminimalkan dampak pandemi covid-19 pada anak usia dini tersebut.

Dari uraian diatas menunjukkan pentingnya kita untuk mengetahui dampak yang dirasakan anak usia dini, maka dengan penelitian ini peneliti ingin membedah secara mendalam dampak apa saja yang dirasakan anak usia dini terkait dengan adanya pandemi virus corona (covid-19). Penelitian ini bertujuan untuk memberikan informasi secara mendalam dari hasil analisis review berbagai literatur terkini tentang dampak pandemi yang dialami anak usia dini. Dari hasil penelitian ini diharapkan guru, orangtua, dan berbagai pihak yang berada di lingkungan sekitar anak usia dini dapat memahami dampak yang dialami anak sehingga dapat berkolaborasi untuk meminimalisir dampak pandemi covid-19 bagi anak usia dini. Dengan begitu anak usia dini tetap dapat belajar dengan bahagia dan menyenangkan meskipun masa pandemi belum berakhir. 


\section{METODOLOGI}

Penelitian kepustakaan ini bertujuan untuk menganalisis dampak apa saja yang dialami anak usia dini pada masa pandemi covid-19. Pada penelitian ini peneliti menggunakan bahan dari literatur terkini sebagai sumber data yang terbagi atas sumber data primer dan data sekunder, data primer adalah data pokok yang menjadi acuan ini antara lain ebook dan jurnal dari unicef, jurnal ilmiah internasional, artikel yang berkaitan dengan anak dan covid-19. Sedangkan sumber data sekunder dalam penelitian ini adalah berita-berita ter-update yang berkaitan dengan covid-19. Penelitian kepustakaan atau library research merupakan penelitian yang dilakukan dengan bantuan infomasi kepustakaan sepeti buku, ebook, yearbook, bulletin, jurnal artikel (Setiawan, 2017).

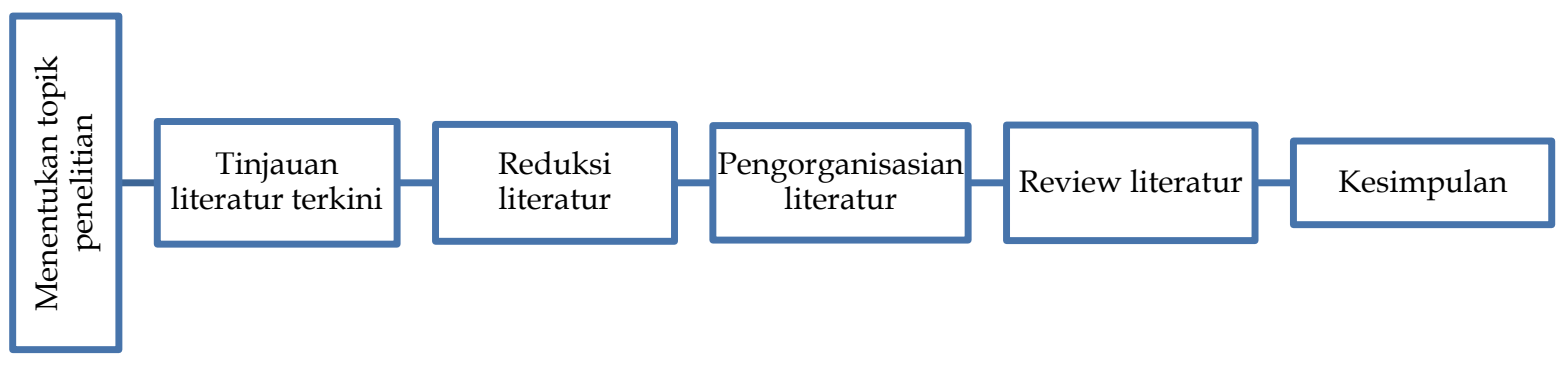

Gambar 1.1 Langkah Penelitian

Untuk menganalisis data peneliti menggunakan teknik analisis data kualitatif karena data-data yang digunakan bukan berupa angka melainkan kepustakaan. Metode untuk menganalisis data menggunakan metode deskriptif dengan tujuan agar hasil analisisnya dapat dijabarkan secara mendalam, terperinci, dan detail. Penelitian ini diawali dengan penentuan topik penelitian yang dilanjutkan dengan meninjau literatur terkini, reduksi literatur, pengorganisasian literatur, review literatur dan pengambilan kesimpulan.

\section{HASIL DAN PEMBAHASAN}

Wabah pandemi corona virus (covid-19) masih kita rasakan hingga saat ini, dampak yang terjadi dari pandemi corona virus semakin hari semakin bertambah. Kemerosotan ekomoni orangtua juga berdampak pada anak usia dini, tidak hanya itu usaha dan upaya pemerintah dalam mengambil kebijakan juga dapat menyebabkan dampak bagi anak. Berikut ini adalah dampak pandemi covid-19 terhadap anak usia dini :

\section{Emosi Yang Tidak Stabil}

Upaya kebijakan pemerintah untuk belajar dari rumah, bekerja dari rumah, dan ibadah dari rumah atau disebut dengan work from home membuat dampak negatif bagi ekonomi keluarga data dari bank dunia menujukkan bahwa pada tahun 2019 setidaknya $10 \%$ dari penduduk indonesia akan mengalami kemiskinan tingkat tinggi dan meningkat hingga $13 \%$ bagi anak-anak dan remaja. Dari persentase tersebut menunjukkan bahwa terjadinya kesenjangan ekonomi yang di sebabkan oleh berkurangnya pendapatan rumah tangga yang akan mempengaruhi kesejahteraan anak. Setidaknya terdapat 9 dari 10 anak mengalami penurunan kesejahteraan antara lain penurunan makanan sehat dan bergizi, sanitasi, kesehatan, dan perlindungan anak (Unicef, 2017). Data dari bank dunia menunjukkan bahwa 52 juta orang yang dikatakan dengan pendapatan aman (Dunia, 2019: $8)$.

Pembelajaran via online yang mengharuskan anak berinteraksi dengan teman dan guru mengharuskan anak memiliki perangkat lunak komputer atau laptop, minimal menggunakan smartphone. Sebuah kasus terjadi, ketika ada keluarga dengan jumlah anak 3 usia sekolah semua pembelajaran dengan via online dan ada jadwal di jam yang sama. Bisa dibayangkan pastilah akan berebut laptop karena semua merasa butuh sedangkan laptop 
yang ada hanya 1, belum lagi jika laptonya akan digunakan ayah untuk bekerja (Wiratama, 2020) . Sehingga anak mengerjakan tugas sekolah secara bergantian dengan saudaranya hingga larut malam. Bisa dibayangkan emosi mereka akan kacau jika tidak memiliki kesabaran yang tinggi karena semua merasa penting, semua merasa butuh, semua ingin mempriorotaskan tugasnya. Namun apa yang terjadi jika antara satu dengan yang lainnya tidak bisa mengontrol emosinya, tentu akan menjadi bentrok antar saudara karena jika tidak hadir dalam pembelajaran via online tentu anak tidak akan mengetahui paparan materi dari guru beserta tuganya. Selain itu anak juga tidak dapat berdiskusi dengan teman-temannya.

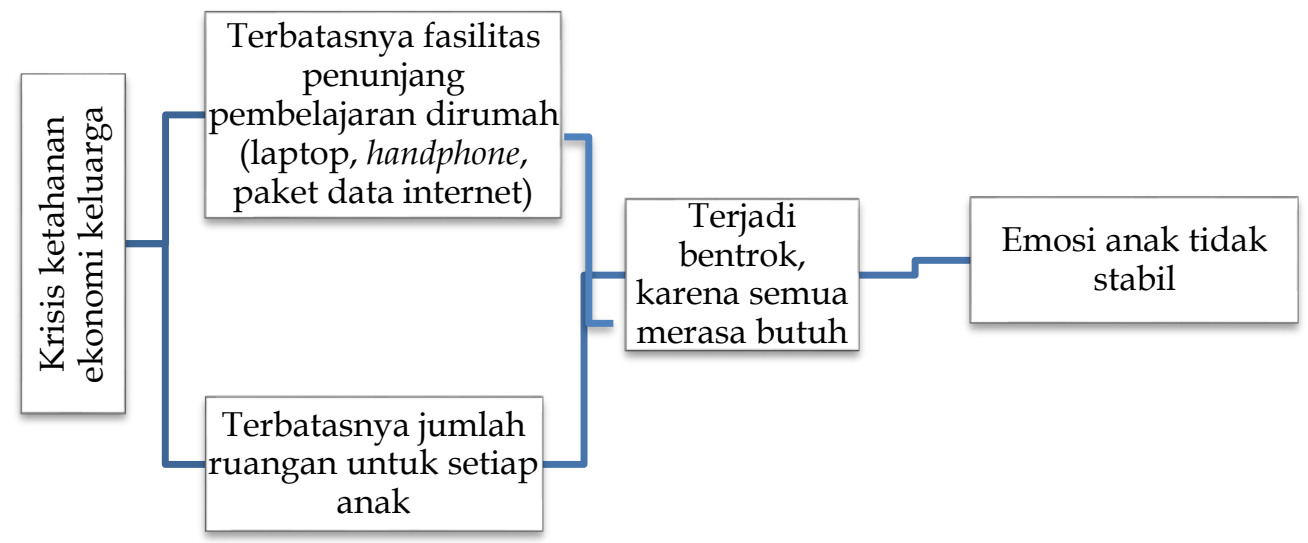

Tabel 2.1 Skema Terjadinya Emosi Tidak Stabil

Tidak hanya itu kasus serupa juga terjadi di pelosok nusantara yang memiliki hambatan dengan signal yang tidak menjangkau kawasan tersebut dan minimnya fasilitas kuota internet. Tidak adanya signal dan mendesaknya pengumpulan tugas membuat hati menjadi bimbang dan berpengaruh terhadap emosinya. Hal ini merupakan contoh konkret ekomoni keluarga memberi dampak emosi yang tidak stabil pada anak.

\section{Krisis Gizi dan Kesehatan}

Data dari kementerian kesehatan pada tahun 2018 menunjukkan setidaknya 7 juta anak di indonesia mengalami stunting, lebih dari dua juta anak dibawah lima tahun mengalami berat badan kurus dan obesitas dan hampir 50\% ibu hamil mengalami anemia (RISKEDAS, 2018). Dari data tersebut menunjukkan bahwa sebelum datang pandemi covid19 saja negara Indonesia dalam memenuhi kebutuhan gizi terhadap anak dan ibu hamil saja masih kurang apalagi jika ditambah dengan datangnya pandemi covid-19 ini. Jika kondisi ini terus berlangsung maka anak akan mengalami malnutrisi karena berbagai sebab, antara lain: (1) pola makan yang buruk akibat dari dampak penurunan keuangan rumah tangga (2) nutrisi yang tidak sesuai dengan standar (3) rendahnya tingkat kebersihan, rendahnya akses kesehatan, dan tingginya angka penyakit menular seperti covid-19 (Unicef, 2018).

Berdasarkan survei online dari (Hanna \& Olken, 2020) bahwa dampak dari pandemi yang berakibat dari menurunnya ketahanan pangan keluarga setidaknya terdapat $36 \%$ dari responden mengaku bahwa dirinya telah mengurangi porsi makan karena terkendala keuangan. Di Indonesia terdapat beberapa jenis bantuan untuk dibagikan pada warga yang terdampak covid-19 namun bantuan tersebut kurang memenuhi kebutuhan anak usia dini bantuan yang tersalurkan lebih banyak berupa sembako yang merupakan keburuhan makro. Padahal anak membutuhkan zat gizi mikro seperti vitamin, mineral, sulfur, zat besi, seng, yodium untuk mengoptimalkan tumbuh kembangnya (Furkon, 2014: 1 - 53). Gizi buruk merupakan bentuk bahwa anak kekurangan gizi, resiko gizi buruk ini terjadi 12x lipat lebih tinggi jika dibanding dengan kematian anak dengan gizi normal. Terlebih pada masa pandemi ini keuangan keluarga menurun, bantuan pemerintah kurang berpihak pada anak usia dini akan memperparah resiko gizi anak indonesia meningkat tajam (Black et al., 2008: $243-260)$. 


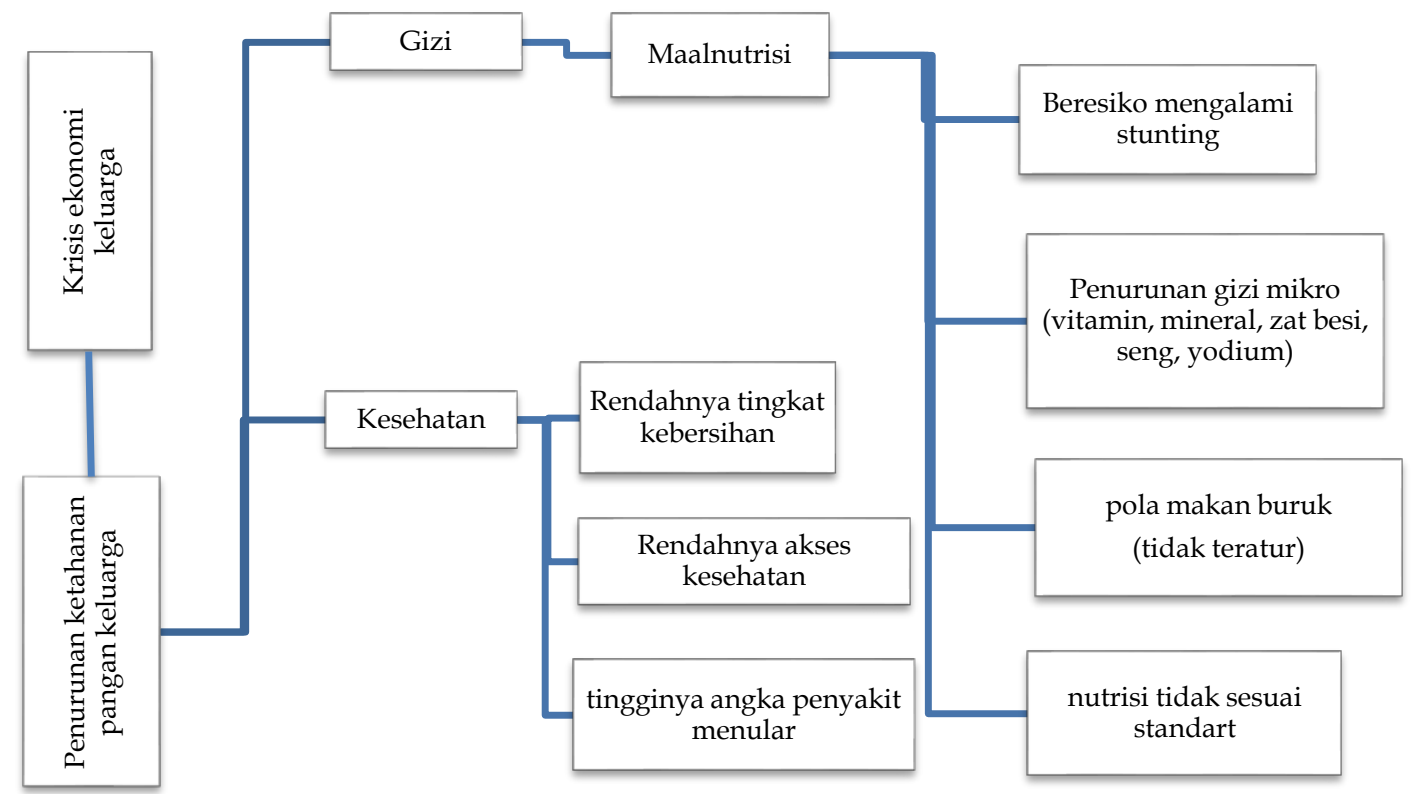

Tabel 2.2 Skema Terjadinya Krisis Gizi dan Kesehatan

Jika kondisi seperti ini terus terjadi, maka kemungkinan anak menderita kekurangan gizi (wasting) dan gagal tumbuh tubuh dan otak (stunting) akan terus meningkat. Data di lapangan menunjukkan terjadinya peningkatan 15\% atau setara dengan 7 juta anak mengalami stunting (Litha, 2020). Inilah mengapa kita perlu untuk tetap menjaga ketahanan pangan keluarga karena akan berdampak pada pemenuhan zat gizi agar tidak terjadi wasting dan stunting pada anak. Maka penting bagi pemerintah untuk memberikan bantuan tidak hanya berupa sembako akan tetapi ditambah dengan susu, vitamin, buah, ikan untuk memenuhi kebutuhan anak.

\section{Gap Pembelajaran}

Pemberlakuan work from home dan physical distancing mengharuskan sekolah-sekolah meliburkan muridnya. Anak usia dini belajar dengan cara bermain, lalu bagaimana jika sekolahnya libur padahal di sekolah anak dapat berinteraksi dengan banyak teman. Tentu hal ini akan berdampak pada psikologinya, selain itu perintah untuk melaksanakan physical distancing untuk anak usia dini juga tidak gampang. Kebijakan ini akan menimbulkan gangguan pembelajaran (Activity, 2020: 2 - 5). Secara alamiah anak akan senang bermain, bermain dan bermain dengan temannya (Musbikin, 2010: 74).

Pembelajaran via online pada saat ini menjadi cara ampuh dalam dunia pendidikan untuk tetap melaksanakan pembelajaran untuk mencapai indikator materi. Padahal berhasilnya pembelajaran online tergantung pada bunda guru, alat pembelajaran (laptop), dan muridnya. Tidak semua pembelajaran online berjalan dengan optimal. Konektivitas harus benar-benar terbuhung dengan baik, berbagai kota di indonesia dengan jangkauan internet yang rendah akan kesulitan untuk mengikuti pembelajaran online. Pembelajaran online menuntut bunda guru untuk terus kreatif dan terampil untuk menggunakan teknologi, terus malakukan pembaharuan media belajar yang menarik dan beda agar anak tidak bosan.

Di Indonesia tidak jarang bunda guru memberikan daftar list tugas, orangtua mengambil tugas di sekolah yang harus di kerjakan murid di rumah. Orangtua menggantikan penuh peran guru dirumah. Orangtua menggantikan peran penuh bunda guru ini akan memberikan dampak yang tidak baik pada anak. Tidak semua orangtua memahami perkembangan anak, tidak semua orangtua mengerti cara menstimulasi yang baik dan benar agar mencapai hasil yang optimal. Jika hal ini dilakukan secara terusmenerus maka akan terjadi gap pembelajaran. 
Pemerintah negara Spanyol meminta bunda guru untuk menyiapkan konten yang menarik agar murid tidak bosan dan tetap bersemangat belajar walaupun dirumah. Tidak hanya menyiapkan konten akan tetapi juga menawarkan kelas online, hal ini dapat dilaksanakan karena adanya konektivitas guru, alat perangkat yang baik. Dalam hal ini jika bunda guru belum paham tentang teknologi maka bunda guru segera belajar dengan kilat. Pemerintah negara Singapura memberikan pelatihan guru secara online terkait strategi pendidikan hingga pembelajaran online. Pelatihan teknologi terbaru ini dirasa sangat perlu pada masa pandemi covid-19, ini menunjukkan bahwa pembelajaran harus tetap berjalan dengan berbagi upaya.

Beralihnya pembelajaran tatap muka ke pembelajaran online merupakan transisi pembelajaran yang dianggap efektif saat ini, namun semua itu harus dipertimbangkan apakah sekolah mampu untuk menawarkan kelas yang berkualitas yang didukung dengan pemahaman orangtua yang baik. Jika tidak, maka ini dapat memperburuk dan menyebabkan ketidaksetaraan pembelajaran. Bahkan negara bagian di negara brazil yang merupakan negara kaya akan tetapi bunda guru tidak memiliki keakraban dengan alat perangkat pendidikan berbasis internet, karena ketidakakraban tersebut pada masa pandemi covid-19 ini menyebabkan penurunan pembelajaran yang sudah baik di negara Brazil (Activity, 2020: 2 - 5). Berikut data penggunaan alat perangkat di negara Brazil.

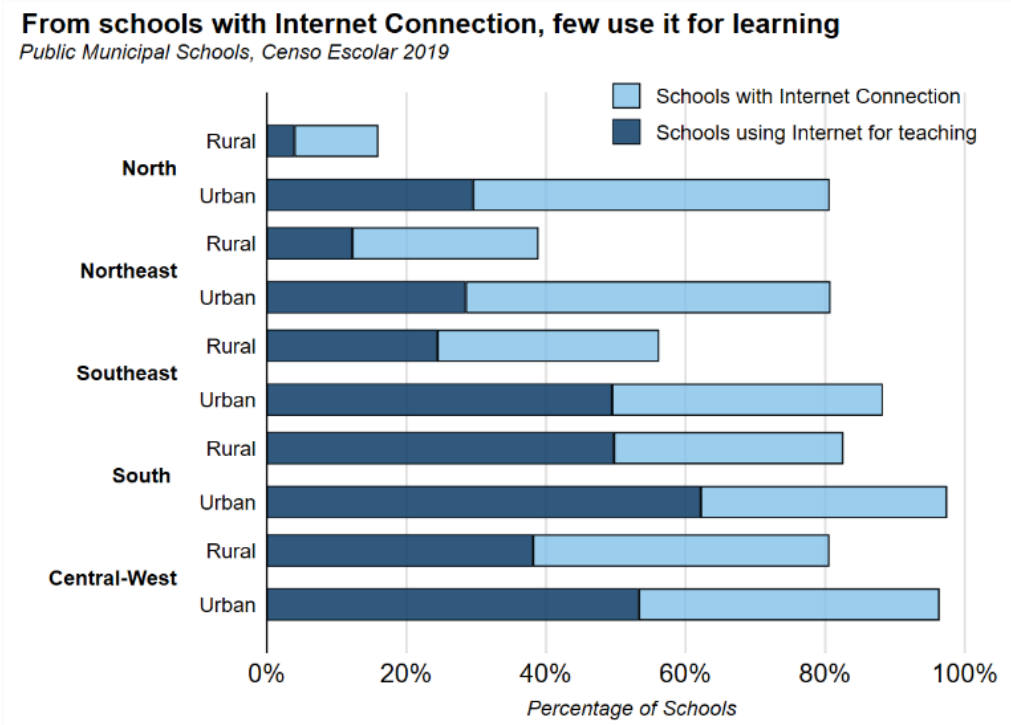

Gambar 2.3 Penggunaan Internet Dalam Pembelajaran Di Brazil

Hasil penelitian di negara Brazil menunjukkan bahwa dampak negatif terjadinya transisi pembelajaran online disebabkan karena bunda guru kurang akrab dengan strategi pembelajaran online yang menarik, kurangnya insentif keluarga untuk mengakses pembelajaran online, dan ketidakselarasan pembelajaran (yang diajarkan di kelas berbeda dengan apa yang diajarkan secara online).

Untuk mensukseskan pembelajaran secara online ini harus adanya kolaborasi antara bunda guru dengan orangtua. Orangtua dan bunda guru harus saling mendukung memerankan tugasnya masing-masing, tentu saja tugas orangtua pada masa pandemi seperti ini semakin meningkat. Tugas bunda guru (1) membuat aplikasi berbasis pendidikan atau sederhananya membuat grup pendidikan. Setidaknya terdapat 2 grub yaitu grub dengan pendidik lain yang tujuannya untuk sharing informasi terkait pembelajaran jarak jauh beserta perangkatnya. Yang kedua grub dengan wali murid yang bertujuan untuk berbagi informasi terkait tugas untuk murid, perkembangan anak, parenting, dan sebagainya. (2) Mengidentifikasi kejuaraan untuk mendukung kegiatan pendidikan secara lokal bagi komunitas sekolah. (3) memantau kegiatan yang dilakukan murid. Tugas orangtua antara lain (1) memproduksi bahan ajar sesuai dengan instruksi dari bunda guru untuk melakukan 
setiap tugas kegiatan. (2) Mengembangkan rutinitas gemar belajar bersama dengan anak. (3) Memberikan dukungan spiritual - emosional kepada anak. (4) aktif dalam kegiatan parenting online atau diskusi yang diselenggarakan sekolah. (5) Menjaga hubungan dekat dengan orangtua lainnya untuk diskusi materi parenting. Maka untuk mengatasi dampak ini orangtua dan guru harus saling bersinergi untuk menciptakan pembelajaran efektif guna mencapai tujuan pembelajaran yang optimal.

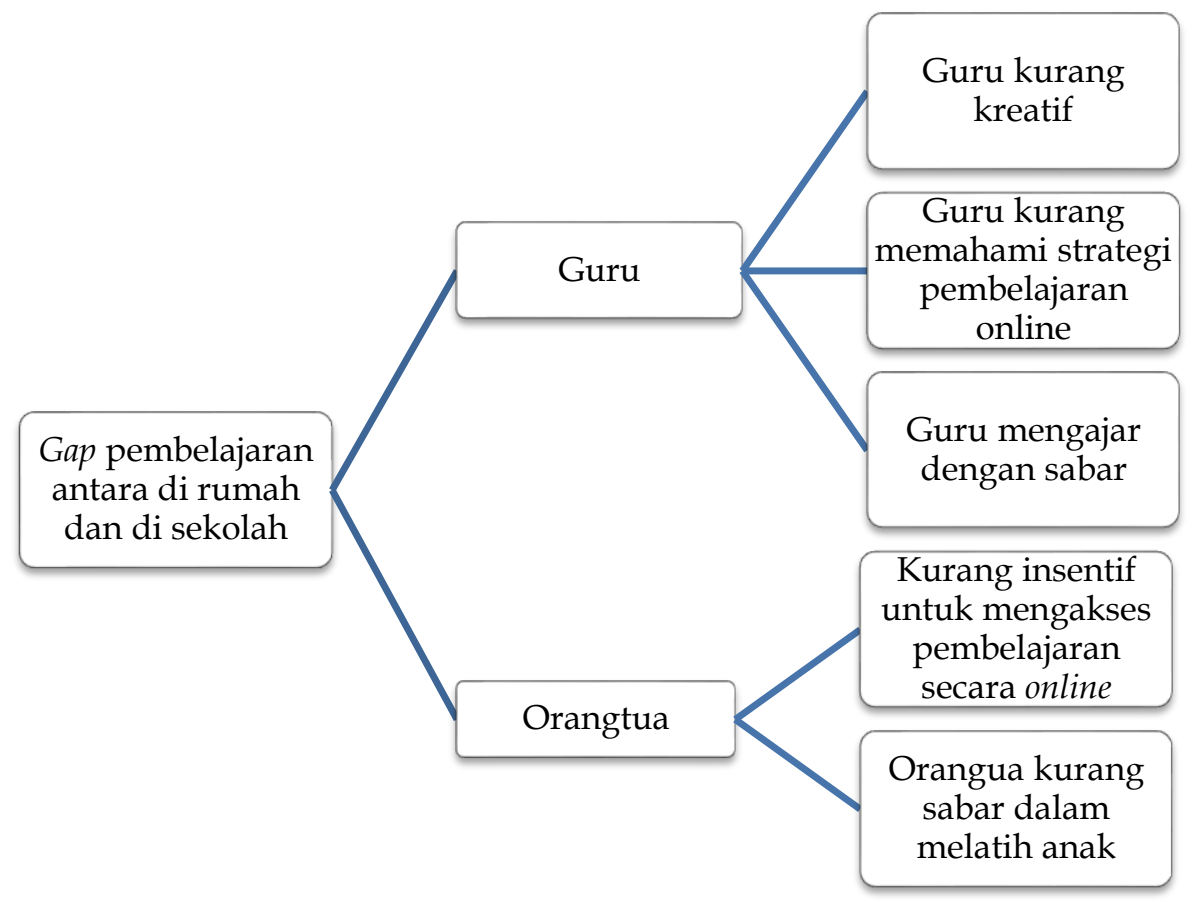

Gambar 2.4 Skema Terjadinya Gap Pembelajaran

Jika di negara Spanyol mempunyai kebijakan untuk memberikan penguatan dengan mengadakan pelatihan bagi guru untuk membuat konten pembelajaran, berbeda dengan negara Indonesia yang memilih menciptakan berbagai strategi untuk membuat anak antusias belajar. Hasil penelitian (Nurul Fadlilah, 2021: 373-384) menunjukkan bahwa anak termotivasi belajar dengan menggunakan strategi publikasi. Adanya publikasi hasil karya oleh bunda guru, anak dapat terpancing untuk segera menyelesaikan tugas agar hasil karyanya di publikasikan oleh bunda guru. Dengan begitu anak akan termotivasi untuk segera menyelesaikan tugasnya. Kemudian penelitian yang dilakukan oleh (Nurkolis \& Muhdi, 2020: 212) rumusan kebijkan e-learning ditinjau secara teoritis dan praktis bersifat sangat efektif akan tetapi dalam penerapannya belum efektif. Hal ini disebabkan karena bunda guru belum siap untuk menerapkan e-learning atau pembelajaran berbasis online.

Kalau saja kedua strategi ini disatukan, dari sisi bunda guru diberi pelatihan agar bunda guru dapat menggunakan e-learning dan pelatihan membuat konten edukatif serta didukung untuk selalu menciptakan strategi pembelajaran yang menyenangkan untuk anak. Maka anak akan senang untuk belajar dan mau untuk menuntaskan berbagai tugas yang diberikan bunda guru.

\section{Krisis Keamanan dan Kenyamanan}

Mayoritas anak usia dini mendefinisikan rumah sebagai termpat yang paling aman dan nyaman dibandingkan dengan tempat yang lain. Rumah juga merupakan sekolah pertama bagi anak, kehidupan awal berada dirumah (Hairuddin, 2014: 84). Sejak adanya kebijakan work from home rumah yang semula menjadi tempat yang paling nyaman kini sejenak berubah, hasil penelitian (Sari, dkk, 2021: 476-489) menunjukkan bahwa intensitas bertemu antara anak dan orangtua sepanjang hari menyebabkan anak menjadi bosan dan rewel. Sementara ibu juga merasakan kebingungan untuk melakukan kegiatan apa dirumah 
bersama anak. Jika orangtua tidak sabar dalam menghadapi anak, maka hal ini menjadi awal terjadinya kekerasan pada anak. Data sebelum datangnya pandemi corona menunjukkan kekerasan anak di Indonesia mencapai $60 \%$ pada usia 13 sampai 17 tahun (P. Indonesia, 2018). Angka yang cukup tinggi ini ditambahan dengan hadirnya wabah coronya yang semakin menjadikan angka kekerasan pada anak semakin tinggi.

Kekerasan pada anak meningkat karena adanya berbagai faktor salah satunya adalah faktor karantina. Pada masa pandemi seperti ini banyak wilayah yang telah menerapkan karantina wilayah pada daerahnya masing-masing daerah. Karantina wilayah dapat dilakukan dengan membatasi warga dengan menutup pitu masuk-keluar suatu wilayah tersebut, banyak kota - kota besar yang menerapkan sistem ini sebagai upaya untuk mencegah penyebaran covid-19 (Iqbal, 2020). Upaya ini dinilai efektif untuk memutus rantai penyebaran namun berdasarkan laporan dari berbagai negara karantina wilayah ini berdampak pada kekerasan terhadap anak. Dengan diberlakukannya karantina wilayah ini maka kegiatan ekonomi tidak dapat berjalan dengan normal yang surutnya pendapatan yang berakibat pada meningkatnya tekanan kebutuhan bagi orangtua yang menimbulkan depresi yang dilampiaskan pada anak (Hutchins \& Enomoto, 2020).

Kekerasan pada anak tidak hanya terjadi di rumah, ketika pemerintah sudah menerapkan kebijkan work from home segala pembelajaran di lakukan via online. Hal tersebut juga berdampak negatif bagi kekerasan anak. Anak akan mengalami ketergantung kemudian jika dalam pembelajaran anak tidak di dampingi orangtua maka anak rentan terkena resiko paparan konten yang tidak pantas bagi usianya dan rentan dengan predator online (Brief, 2020: 10). Tidak ada salahnya jika anak tumbuh dengan digitalisasi karena memang anak sudah lahir di zaman digital namun semua itu harus dengan pengawasan jika tidak berbagai gangguan seperti keterlambatan dalam berbicara, antisosial, gangguan emosional dan sebagainya akan mengintai anak (Sundus, 2017: 1-3).

Pada masa pandemi seperti ini sekolah sebaiknya menyelenggarakan kegiatan parenting dengan intensitas lebih tinggi dari biasanya. Hal ini dikarenakan untuk mengurangi pemahaman tentang bagaimana memberikan keamanan dan kenyamanan pada anak agar anak tetap bahagia di rumah. Dengan begitu maka akan dapat mengurangi kekerasan pada anak selama pandemi. Dari uraian panjang diatas menunjukkan bahwa peran orangtua dalam memberikan keamanan dan kenyamanan pada anak sangat penting untuk pertumbuhan dan perkembangan anak yang optimal.

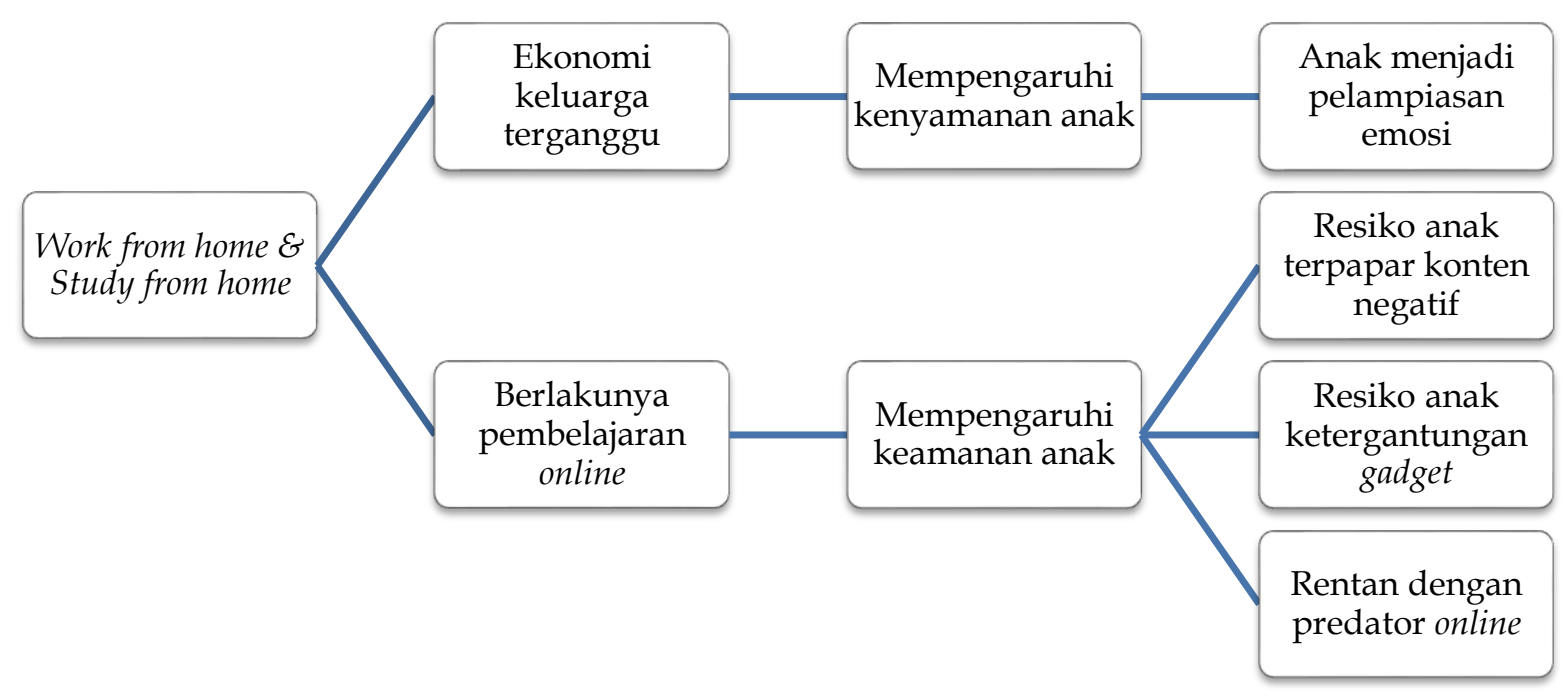

Gambar 2.5 Skema Terjadinya Penurunan Keamanan dan Kenyamanan 
Orangtua sebagai pemegang kendali keamanan dan kenyamanan dirumah harus dapat memberikan yang terbaik, harus melindung anak dari berbagai resiko dan paparan gadget. Pada kenyataannya disaat pandemi seperti ini orangtua kurang memahami apa yang harus dilakukan. Hal ini menyebabkan krisis keamanan dan kenyamanan anak.

\section{Krisis Pengasuhan}

Pada masa pandemi covid-19 anak-anak mengalami krisis pengasuhan positif. Pengasuhan positif menurut kementerian pendidikan dan kebudayaan adalah pengasuhan yang berlandaskan pada kasih sayang, menghargai anak, membangun interaksi yang baik antara anak dengan orangtua, dan menstimulasi anak agar tumbuh dan berkembang secara optimal. Pengasuhan yang menerapkan pemberian reward, pemenuhan hak anak, dan mengedepankan kepentingan anak (Djaja dkk, 2016) . Namun tidak semua orangtua mampu untuk memenuhi kebutuhan anak secara menyeluruh pada saat pandemi.

Setidaknya terdapat 5 kebutuhan dasar menurut Abraham Maslow antara lain: (1) Kebutuhan fisiologi (makan yang bergizi, minum, baju), kondisi ekonomi yang semakin menurun akibat pandemi membuat ketahanan pangan keluarga menurun akibatnya keluarga makan denagan makanan seadanya, hal ini membuat gizi anak tidak terpenuhi dengan seimbang. (2) Kebutuhan rasa aman (keamanan, kenyamanan, keteraturan), sejak berlakunya kebijakan work from home dan pembelajaran berbasis online membuat intensitas anak memegang gadget lebih sering dan lama. Hal ini membuat resiko anak terpapar konten negatif meningkat, yang mengakibatkan keamanan anak menurun. (3) sosial (interaksi antar teman, keluarga), adanya himbauan untuk physical distancing membuat kebutuhan bermain anak tidak terpenuhi. Anak juga tidak boleh berdekatan dengan temannya, hal ini membuat kebutuhan sosial anak tidak dapat terpenuhi. (4) kebutuhan penghargaan (reward verbal maupun materil), tidak sedikit orangtua memberikan penghargaan secara materil berupa mainan, akan tetapi pada saat seperti ini orangtua tidak bisa memberikan penghargaan tersebut sebab toko alat permainan edukatif masih tutup. Orangtua hanya bisa memberikan penghargaan secara verbal akan tetapi anak terus meminta mainan. Dalam hal ini orangtua memiliki keterbatasan untuk memberikan penghargaan kepada anak. (5) Kebutuan aktualisasi yaitu mengembangkan anak dengan mengikutkan dalam berbagai les sesuai dengan bakat dan minat anak, akan tetapi pada masa pandemi saat ini hampir semua les atau kursus meliburkan siswa-siswinya. Meskipun beberapa kelas kursus memberikan layanan online, akan tetapi untuk bidang tertentu seperti menari, memanah, dan berenang tidak dapat berjalan dengan optimal (Wiresti, 2020: 36-44). Dari lima dasar diatas sulit bagi orangtua untuk memenuhi kebutuhan aktualisasi anak dan sosial anak. Kondisi saat ini belum memungkinkan untuk anak bepergian keluar rumah, apalagi bertemu dengan temannya.

Dalam pengasuhan anak setidaknya ada tiga gaya pengasuhan anak antara lain: (1) pola pengasuhan otoriter yaitu pengasuhan yang berpusat pada orangtua, pada pengasuhan ini anak tidak memiliki kebebasan untuk mengungkapkan pendapat atau mengungkapkan apa yang ia ingin. Anak harus selalu menurut pada orangtua, jika tidak maka anak akan diberi hukuman. (2) pola pengasuhan demokratis yaitu pengasuhan yang berlandaskan demokrasi artinya orangtua mendengarkan pendapat atau keinginan anak kemudian melakukan musyawarah bersama untuk menentukan kesepakatan bersama. Dalam musyawah orangtua berperan $50 \%$ dan anak berperan $50 \%$ jadi dalam pola ini dapat dikatana kolaborasi orangtua dengan anak. (3) pola permissif yaitu pengasuhan dimana orangtua membebaskan anaknya untuk berperilaku. Dapat dikatakan pola ini adalah kebalikan dari pola otoriter (Lestari, 2008: 51). Pada saat ini karena situasi mendesak sehingga orangtua beresiko mengalami stres atau depresi disebabkan faktor ekonomi keluarga yang menurun kemudian dilampiaskan pada anak otomatis ini akan mempengaruhi pola pengasuhannya. Banyak orangtua pada saat ini yang menerapkan pola 
DOI: 10.31004/obsesi.v5i1.563

otoriter bahkan ketika anaknya tidak melakukan apa yang orangtua mau, maka tak segan orangtua akan menghukumnya.

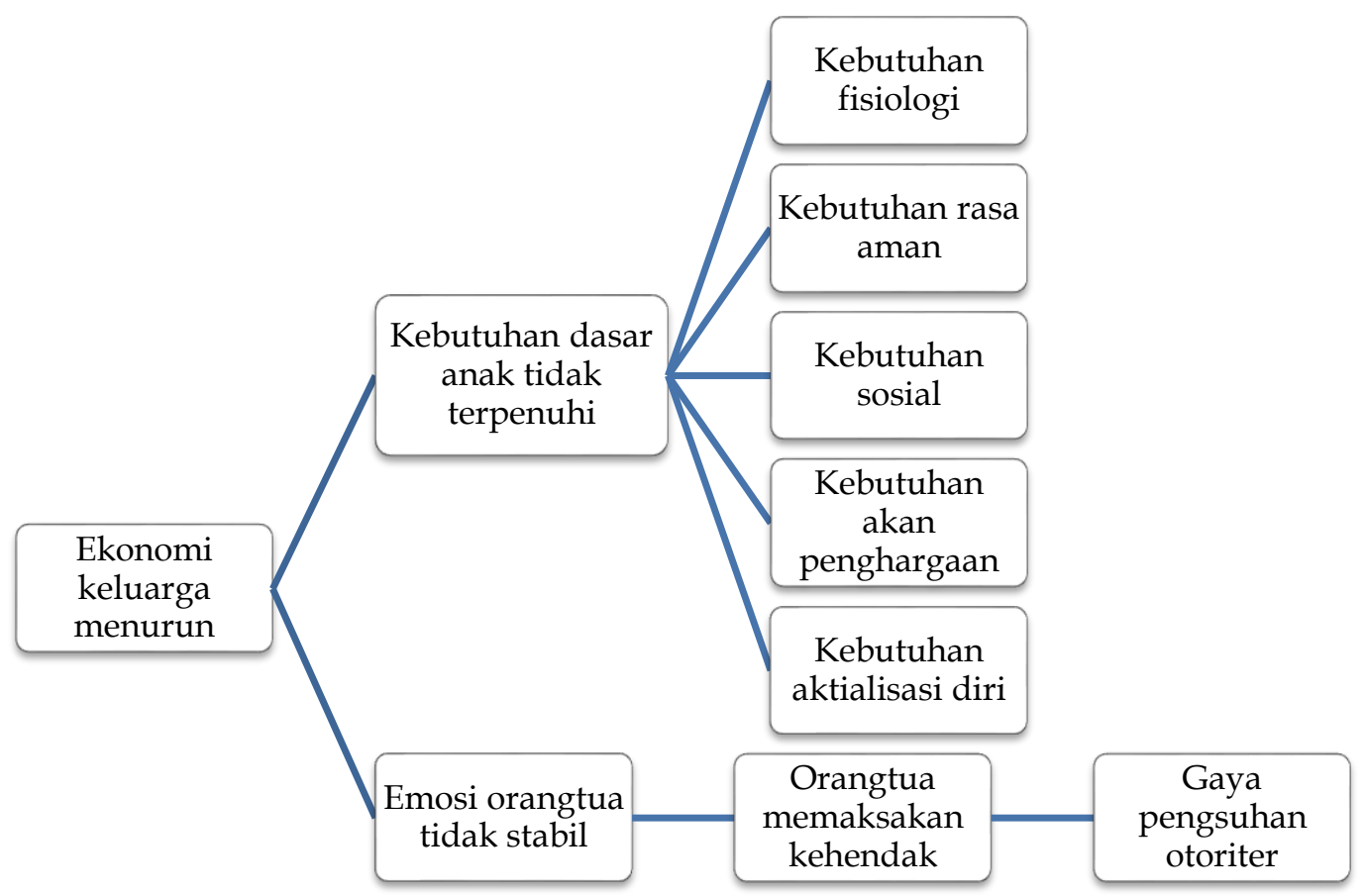

Gambar 2.6 Skema Terjadinya Krisis Pengasuhan

Penerapan gaya pengasuhan otoriter ini jika dibiarkan terjadi akan berdampak bagi perkembangan anak, yang paling menonjol dari dampak pengasuhan ini adalah perkembangan sosial-emosionalnya. Tidak sedikit anak yang sulit untuk berinteraksi dengan teman sebayanya bahkan ada yang sering menyakiti teman sebagai pelampiasan atas emosinya. Hal ini dukung oleh penelitian (Novianty, 2016: 17-25) yang menyatakan bahwa tinggi rendahnya kecerdasan emosi dapat dilihat dari tinggi rendahnya pengasuhan otoriter yang dilakukan orangtua terhadap anak. Maka dari itu sebagai orangtua diharapkan untuk tetap tenang dan menjaga kestabilan emosi karena apa yang dilakukan orangtua akan berpengaruh terhadap perkembangan anak usia dini.

\section{SIMPULAN}

Dari hasil penelitian ini dapat disimpulkan bahwa kebijakan pemerintah untuk work from home memberi dampak yang signifikan. Kebijakan work from home menimbulkan krisis ketahanan ekonomi keluarga, dari krisis ekonomi keluarga tersebut muncul berbagai dampak bagi anak antara lain: (1) Terbatasnya fasilitas penunjang pembelajaran, yang berakibat pada emosi anak tidak stabil, (2) Penurunan ketahanan pangan keluarga, yang berakibat pada terjadinya krisis gizi dan kesehatan anak, (3) Guru kurang memahami $e$ learning dan orangtua kurang mengakses pembelajaran online, menimbulkan gap pembelajaran (4) Anak sebagai pelampiasan emosi ketika ekonomi keluarga menurun, berakibat pada krisisnya keamanan dan kenyamanan anak, (5) Kebutuhan dasar anak yang tidak terpenuhi dan beralihnya gaya pengasuhan menjadi otoriter, berakibat pada krisisnya pengasuhan pada masa pandemi.

\section{UCAPAN TERIMA KASIH}

Alhamdulillah, atas berkat rahmat Allah SWT dan taufiq hidayahNya penulis dapat menyelesaikan proses penelitian ini hingga selesai. Mulai dari menelaah teori, studi teoritik, studi linguistik serta studi berbagai karya sastra. Penelitian ini belum sepenuhnya 
sempurna, maka dalam hal ini peneliti terbuka jika ada masukan, kritik, dan saran yang bertujuan untuk menyempurnakan penelitian ini. Semoga hasil dari penelitian ini dapat memberikan manfaat serta menambah pengetahuan bagi pembaca. Amin.

\section{DAFTAR PUSTAKA}

Activity, E. (2020). What Can Brazil Learn From The Rest Of The. 131(2), 2-5.

Asia, chanel news. (2020). "Indonesia's health system on the brink as coronavirus looms."

Bender, L. (2020). Key Messages and Actions for Prevention and Control in Schools. Unicef, (March), 2.

Black, R. E., Allen, L. H., Bhutta, Z. A., Caufield, L. E., Rivera, J., Mathers, C., ... Onis, M. de. (2008). Maternal and child undernutrition: global and regional exposures and health consequences. The Lancet, 371(materia and child undernutrition), 243-260. https:/ / doi.org/10.1016/S0140-6736(07)61690-0

Brief, P. (2020). Policy Brief: The Impact of on children (p. 10). p. 10.

Dewayani, T. (2020). Bekerja dari Rumah (Work From Home) Dari Sudut Pandang Unit Kepatuhan Internal.

Retrieved from https://www.djkn.kemenkeu.go.id/artikel/baca/13014/Bekerja-dari-Rumah-WorkFrom-Home-Dari-Sudut-Pandang-Unit-Kepatuhan-Internal.html

Djaja, M., Nirawaty, N., Darnis, S., Zakaria, M. R., Hayati, L., \& Yuniarti, S. L. (2016). Buku Saku Pengasuhan Positif-edLina.pdf. Jakarta.

Dunia, G. B. (2019). Aspiring Indonesia - Expanding the Middle Class. Washington, D.C., p. 8. Furkon, L. A. (2014). Mengenal Zat Gizi. Ilmu Kesehatan Gizi, 1-53. Retrieved from http:/ / repository.ut.ac.id/4335/2/PEBI4424-M1.pdf

Hairuddin. (2014). Pendidikan Itu Berawal Dari Rumah Hairuddin Institut Agama Islam Negeri Sultan Amai Gorontalo. Pendidikan, 10, 75-91.

Hananti, A. (2020). Ketahui Perbedaan COVID-19 dengan SARS dan MERS. Retrieved from https://www.alodokter.com/ketahui-perbedaan-covid-19-dengan-sars-dan-mers

Hanna, \& Olken. (2020). Hasil Terkini dari Survei Daring tentang Dampak Ekonomi Akibat COVID-19 di Indonesia.

Hutchins, E., \& Enomoto, K. (2020). Returning to resilience: The impact of COVID-19 on mental health and substance use. McKinsey $\&$ Company. Retrieved from https:// www.mckinsey.com/industries/healthcare-systems-and-services/ourinsights/returning-to-resilience-the-impact-of-covid-19-on-behavioral-health

Indonesia, C.-A., \& Indonesia, C.-D. I. (2020). Covid-19 dan Anak-Anak di Indonesia. (April).

Indonesia, P. (2018). Kementerian Pemberdayaan Perempuan dan Anak-Anak. Jakarta: SNPHAR.

Iqbal, M. (2020). Apa Itu Karantina Wilayah \& Bagaimana Mekanismenya? Retrieved from https://www.cnbcindonesia.com/news/20200330130833-4-148452/apa-itukarantina-wilayah-bagaimana-mekanismenya

Lestari, P. (2008). Pola Asuh Anak Dalam Keluarga ( Studi kasus pada pengamen anak-anak di kampung Jlagran, Yogyakarta ). Pola Asuh Anak Dalam Keluarga DIMENSIA, 2(1), 51.

Liang, J., Roberts, J., Ying, Z. J., Cao, J., Qi, M., \& Sun, M. (2015). Does Working From Home Work? Evidence From A Chinese Experiment. The Quarterly Journal of Economics, 130(1), 165-218. https:// doi.org/10.1093/qje/qju032

Litha, Y. (2020). UNICEF Indonesia: Pandemi Diprediksi Tingkatkan Jumlah Kasus Stunting. Retrieved from https://www.voaindonesia.com/a/unicef-indonesia-pandemidiprediksi-tingkatkan-jumlah-kasus-stunting/5485964.html

Makki, S. (2020). Lembaga riset CORE memperkirakan jumlah pengangguran berpotensi bertambah 9,35 juta orang dalam skenario terberat dampak virus corona. Retrieved from https:/ / www.cnnindonesia.com/ekonomi/20200415170121-532-493875/pengamatsebut-skenario-terberat-pengangguran-capai-935-juta

Musbikin, I. (2010). Buku Pintar PAUD (Dalam Perspektif Islami) (1st ed.; Sudjatna, Ed.). 
DOI: 10.31004 /obsesi.v5i1.563

Jogjakarta: Laksana.

Novianty, A. (2016). Pengaruh Pola Asuh Otoriter Terhadap Kecerdasan Emosi Pada Remaja Madya. Jurnal Ilmiah Psikologi Gunadarma, 9(1), 100459.

Nurkolis, N., \& Muhdi, M. (2020). Keefektivan Kebijakan E-Learning berbasis Sosial Media pada PAUD di Masa Pandemi Covid-19. Jurnal Obsesi : Jurnal Pendidikan Anak Usia Dini, 5(1), 212. https:// doi.org/10.31004/obsesi.v5i1.535

Nurul Fadlilah, A. (2021). Jurnal Obsesi: Jurnal Pendidikan Anak Usia Dini Strategi Menghidupkan Motivasi Belajar Anak Usia Dini Selama Pandemi COVID-19 melalui Publikasi. Jurnal Obsesi: Jurnal Pendidikan Anak Usia Dini, 5(1), 373-384. https://doi.org/10.31004/obsesi.v5i1.548

Porter, B. De, \& Hernacki, M. (1999). Quantum Learning (5th ed.; S. Meutia, Ed.). New York: Kaifa.

Prima, E. (2018). Pengaruh Ritme Otak dan Musik dalam Proses Belajar. KOMUNIKA: Jurnal Dakwah Dan Komunikasi, 12(1), 43-57. https:/ / doi.org/10.24090/komunika.v12i1.1351

RISKEDAS. (2018). Kementerian Kesehatan Republik Indonesia.

Sari, D. A., Mutmainah, R. N., Yulianingsih, I., Tarihoran, T. A., \& Bahfen, M. (2021). Kesiapan Ibu Bermain Bersama Anak Selama Pandemi Covid-19, "Dirumah Saja." Jurnal Obsesi: Jurnal Pendidikan Anak Usia Dini, 5(1), 476-489. https://doi.org/10.31004/obsesi.v5i1.548

Sebayang, R. (2020). Alert! WHO Resmi Tetapkan Corona Pandemi. Retrieved from https://www.cnbcindonesia.com/news/20200312064200-4-144245/alert-who-resmitetapkan-corona-pandemi

Setiawan, S. (2017). Studi Kepustakaan. Gurupendidikan.Co.Id, 1. Retrieved from gurupendidikan.co.id/Stud- Kepustakaan-Pengertian-Tujuan-Peranan-SumberStrategi/

Sundus, M. (2017). The Impact of using Gadgets on Children. Journal of Depression and Anxiety, 07(01), 1-3. https:/ / doi.org/10.4172/2167-1044.1000296

Ulfah, M., \& Na'imah. (2020). Peran Keluarga dalam Konsep Psikologi Perkembangan Anak Usia Dini. Aulad: Journal on Early Childhood, 3(1), 20-28. https://doi.org/10.31004/aulad.v3i1.46

Unicef. (2017). Anak-Anak di Indonesia: Analisis Kemiskinan, Mobilitas, dan Kekurangan Multidimensi. Jakarta: Unicef.

Unicef, I. (2018). Kajian Kapasitas Negara Memenuhi Kebutuhan Gizi. Unicef. Jakarta.

Wiratama, A. (2020). Belajar dari Covid-19, New Normal Pendidikan. Retrieved from https://www.inews.id/news/nasional/belajar-dari-covid-19-new-normalpendidikan?page $=$ all

Wiresti, R. D. (2020). Aspek Perkembangan Anak: Urgensitas Ditinjau dalam Paradigma Psikologi Perkembangan Anak. 3(1), 36-44. https://doi.org/10.31004/aulad.v3i1.53

Yuliawan, T. P. (2016). Coaching Psychology: sebuah Pengantar. 19(2), 45-54. https://doi.org/10.22146/bpsi.11556 